\title{
GGE Biplot Analyses for Grain Quality and Yield of Durum Wheat (Triticum turgidum ssp. durum Desf.) Landraces Populations
}

\author{
Alpay Balkan, Oğuz Bilgin and İsmet Başer \\ Department of Field Crops, Faculty of Agriculture, Tekirdă̆ Namık Kemal University, 59030 Tekirdă̆, Turkey
}

\begin{abstract}
The aim of this study was to determine the GY (grain yield) and some quality characters of durum wheat landraces under Thrace Region ecological conditions. This study was carried out in randomized complete blocks design with three replications in the locations of Tekirdağ, Edirne, Kırklareli and Lüleburgaz during the growing years of 2009 and 2010. In the research, 20 durum wheat landraces obtained from different regions of Turkey and 5 obsolete durum wheat cultivars were used as the experimental material. It was determined that the GY, TW (test weight) and PC (protein content) in the first year were higher than the second year in this study. The highest values for GY, TGW (thousand grain weight), and TW and GVR (grain vitreousness rate) were determined in Tekirdağ location, while the highest PC was determined in Edirne location. The results of the research showed that GY varied between 321.17-470.33 kg da ${ }^{-1}$ in Tekirdağ, 301.33-404.00 kg da ${ }^{-1}$ in Edirne; 197.50-334.67 kg da ${ }^{-1}$ in Kırklareli and 280.00-501.33 $\mathrm{kg} \mathrm{da}^{-1}$ in Lüleburgaz. TGWs were determined between 38.17-44.50 g of Tekirda $\breve{g}, 36.00-43.00 \mathrm{~g}$ of Edirne, 38.43-43.67 g of Kırklareli and 35.33-45.67 g of Lüleburgaz. TW of Tekirdağ, Edirne, Kırklareli and Lüleburgaz locations changed between 74.67-79.33 $\mathrm{kg} \mathrm{hl}^{-1}$, 69.33-76.83 $\mathrm{kg} \mathrm{hl}^{-1}$, 70.00-75.17 $\mathrm{kg} \mathrm{hl}^{-1}$ and 71.00-77.50 kg hl-1, respectively. The GVR was determined among 85.00-96.83\% in Tekirdağ, 68.33-93.33\% in Edirne, 67.83-93.83\% in Kırklareli, and 85.17-98.17\% in Lüleburgaz. The PC of grains was measured among 13.32-14.95\% in Tekirdağ, $14.90-16.25 \%$ in Edirne, $14.27-16.17 \%$ in Kırklareli, and $13.40-16.53 \%$ in Lüleburgaz. It was determined that Dicle and Dicle-13 landraces for GY and TW, Adıyaman landrace for TGW, Çanakkale and Akbuğday landraces for the GVR, and İskenderun, Akbuğday, Erzincan landraces for PC have the highest values.
\end{abstract}

Key words: Durum wheat, landraces, GY, quality characters, location.

\section{Introduction}

Wheat is an important crop in Turkey with the planted area of 7.6 million ha and annual production exceeding about 20 million ton [1]. Annual consumption of wheat products in Turkey exceeds 200 $\mathrm{kg}$ per capita and is one of the highest in the world. The presumed center of wheat origin and diversity is situated in the Fertile Crescent [2], which includes part of present-day Turkey. Thus, the diversity of wheat and its wild relatives in Turkey has a global role in providing important genetic resources for wheat improvement.

Durum wheat (Triticum turgidum ssp. durum Desf.,

Corresponding author: İsmet Başer, $\mathrm{PhD}$, professor, research field: cereal breeding.
$2 n=4 x=28, \mathrm{AABB})$ is the 10th most important crop worldwide owing to its annual production of 37 million tons [3, 4]. It is grown on about $10 \%$ of the world's wheat area mostly in West Asia, North, and East Africa, the North American Great Plains, India, Eastern and Mediterranean Europe [5]. Durum wheat is also an important crop in Turkey and in the Mediterranean countries. Its significance has increased due to lack of good quality material for use in the pasta and macaroni industries, its important role in international trade and due to food shortages in many of the world's developing countries [6]. Hence, there is the need to develop durum wheat varieties with high-yielding capacity and better end-use quality. This goal could be realized via intensive breeding programs. 
Durum wheat landraces are less productive, but they are more tolerant to environmental stress than the modern varieties. Some old wheat varieties or landraces are still grown by farmers in traditional farming systems, because of their high end-product quality and, recently, in the framework of organic farming $[7,8]$.

There is growing interest in use of available genetic resources in the development of new durum wheat cultivars that tolerate major biotic and abiotic stresses and for the improvement of crop productivity and quality. This development will require thorough understanding of the available genetic variation in landraces, primitive wheats, and wild relative species. The rate of progress, however, will depend on the presence of genetic variation for desired traits and the availability of reliable methods for the identification, selection, and transfer of superior genes [9]. Wheat landraces adapt to changing climate conditions and to harsh environments, owing to their population genetic structure, buffering capacity, and combinations of agro-physiological traits conferring adaptability to stress environments [10].

Landraces of wheat generally tolerant to biotic and abiotic stress have been grown under low-input or sustainable farming conditions where they produce reasonable yield. A landrace, being composed a mixture of homozygous genotypes, usually exhibits considerable genetic variation for developmental, qualitative and quantitative characters [11].

Grain quality of some wheat landraces should be of special interest because much broader diversity can be found here compared to presently grown cultivars. Ref. [12] referred to the very high PC (protein content) in kernels of some landraces of common wheat. Ref. [13] expressed that the selected landraces had not only high PC but also convenient parameters of some other traits of quality.

The aim of a durum wheat breeding program is to develop new cultivars with high yielding potential and better end-use quality. The semolina milling value can be defined as the capacity of durum wheat to give high yields of semolina of defined purity under industrial conditions [14]. Grain physical quality of durum wheat, which depends on TGW (thousand grain weight) and TW (test weight) influencing semolina production [15], is affected by the degree of vitreousness of the endosperm [16].

The aim of this study was to determine GY (grain yield) and some quality characteristics such as TGW, TW, the GVR (grain vitreousness rate), and PC in some durum wheat landraces under Thrace Region ecological conditions.

\section{Materials and Methods}

This study was carried out in randomized complete blocks design with three replications in the locations of Tekirdağ, Edirne, Kırklareli and Lüleburgaz during the wheat growing years of 2009 and 2010.

The experimental areas' soils were clay-loam, slightly acidic, saltless, limeless, and poor in the organic matter. In the 2008-2009 wheat growing season (November-June), the total precipitation, the average temperature and relative humidity in the locations of Tekirdağ, Edirne, Kırklareli and Lüleburgaz were 314.0, 310.1, 423.8 and $323.0 \mathrm{~mm}$; 11.1, 11.9, 10.1 and $11.0{ }^{\circ} \mathrm{C}$; 82.5, 75.5, 72.6 and $72.4 \%$, respectively. In the second year (2009-2010), the total precipitation, the average temperature and relative humidity in the locations of Tekirdağ, Edirne, Kurklareli and Lüleburgaz were 525.0, 310.1, 423.9, 464.5 and $483.3 \mathrm{~mm} ; 12.2,10.8,10.6$ and $11.0{ }^{\circ} \mathrm{C}$; 83.8, 81.4, 74.9 and $77.6 \%$, respectively. In the research, 20 durum wheat landraces obtained from different regions of Turkey and 5 obsolete durum wheat cultivars were used as the experimental material (Table 1).

These 25 genotypes were tested under rainfed conditions at four locations during the 2009 and 2010 wheat growing seasons. The experiments were laid out in a randomized complete block design with three replicates at each location. The plots' area was $6 \mathrm{~m}^{2}$ (6 
Table 1 Experimental materials used in the study.

\begin{tabular}{lllll}
\hline Durum wheat landraces & \multicolumn{3}{l}{ Obsolete cultivars } \\
\hline 1. Manisa & 6. Tokat & 11. İskenderun & 16. Siverek & 21. Mersiniye \\
2. İzmir & 7. Erzincan & 12. Kahramanmaraş & 17. Dicle & 22. Gökgöl-79 \\
3. Bursa & 8. Akbuğday & 13. Mardin & 18. Dicle-13 & 23. Beyaziye \\
4. Çanakkale & 9. Amasya & 14. Adiyaman & 19. Bağacak & 24. Berkmen-469 \\
5. Denizli & 10. Yozgat & 15. Gaziantep & 20. Kayadere & 25. Bintepe \\
\hline
\end{tabular}

rows, $5 \mathrm{~m}$ long, spaced $20 \mathrm{~cm}$ apart). Genotypes were sown using a seeding rate of 500 seeds $\mathrm{m}^{-2}$ per plot. The plots were fertilized with $50 \mathrm{~kg} \mathrm{ha}^{-1}$ pure nitrogen (N) and $50 \mathrm{~kg} \mathrm{ha}^{-1}$ pure $\mathrm{P}_{2} \mathrm{O}_{5}$ as composed fertilizer at the sowing, $82 \mathrm{~kg} \mathrm{ha}^{-1}$ pure $\mathrm{N}$ as urea $(46 \% \mathrm{~N})$ at the tillering stage, and $40 \mathrm{~kg} \mathrm{ha}^{-1}$ pure $\mathrm{N}$ as ammonium nitrate $(26 \% \mathrm{~N})$ at the pre-heading stage. Also, standard cultural practices such as weed control were also followed for wheat growing.

In the study, the GY, TGW, TW, the GVR and PC were investigated.

The variance analysis on obtained data was performed according to the factorial randomized complete blocks design using the JUMP 5.0 statistical package program, and the differences between the averages were determined by Student's test.

\section{Results and Discussion}

\subsection{Results of Variance Analyses}

The study was carried out in 4 different locations and two years with 20 durum wheat landraces and 5 durum wheat obsolete cultivars. In this study variance analyses were made for GY, TGW, TW, GVR and PC values and mean values and significance groups were given separately.

As a result of the analysis of variance of the obtained characters values from 4 different locations during two years in durum wheat genotypes, year, location, genotype and location x genotype interaction were found to be statistically significant (Table 2). In the study, the first year (353.27 $\mathrm{kg} \mathrm{da}^{-1}$ ) gave higher average GY than the second year (314.50 kg da ${ }^{-1}$ ). The highest GY was found from $389.35 \mathrm{~kg} \mathrm{da}^{-1}$ with
Tekirdağ location, followed by Edirne with $353.65 \mathrm{~kg}$ $\mathrm{da}^{-1}$. The lowest GY was determined in Kirklareli location with $253.68 \mathrm{~kg} / \mathrm{da}$. In the locations, there was a yield difference of approximately $140 \mathrm{~kg} \mathrm{da}^{-1}$. The mean GY of landraces and obsolete cultivars ranged from 302.79 to $414.42 \mathrm{~kg} \mathrm{da}^{-1}$. The highest yield was obtained from 419.42 and $405.42 \mathrm{~kg} \mathrm{da}^{-1}$ and Dicle and Dicle-13 genotypes. Kahramanmaraş and Siverek landraces followed these genotypes with 384.83 and $376.42 \mathrm{~kg} \mathrm{da}^{-1}$. The lowest yields were determined in the landraces of Çanakkale, İskenderun and Kayadere köyü with 302.79, 303.58 and $303.96 \mathrm{~kg} \mathrm{da} a^{-1}$, respectively.

Analysis of the variance in the thousand-weight values was found to be statistically significant years, locations, genotypes and location $\mathrm{x}$ genotype interactions (Table 2). In the first trial year, TGW was determined as $39.91 \mathrm{~g}$ and increased to $40.77 \mathrm{~g}$ in the second year. When the locations were examined, the highest TGW was observed in Tekirdağ with 42.05 g, followed by the locality of Lüleburgaz with $41.55 \mathrm{~g}$. The lowest TGW value was obtained from Kirklareli location with $38.87 \mathrm{~g}$ (Table 2). TGW values in durum wheat genotypes ranged from 43.54 to $36.58 \mathrm{~g}$. The landrace of Adiyaman, with $43.54 \mathrm{~g}$ of genotypes, had the highest TGW value, followed by the Çanakkale landrace with $42.67 \mathrm{~g}$ and the Gaziantep landrace with $42.54 \mathrm{~g}$. The lowest TGW was found in the Mardin landrace with $36.58 \mathrm{~g}$. The landrace of Iskenderun with $38.46 \mathrm{~g}$ and the Manisa landrace with $38.54 \mathrm{~g}$ were listed later.

In the analysis of TW, years, locations, genotypes and location $\mathrm{x}$ genotype interactions were found to be statistically significant (Table 2). The higher TW 
values were obtained in the first year of the experiment (Table 2). The highest TW among the locations was obtained from Tekirdağ with $77.11 \mathrm{~kg}$ $\mathrm{hl}^{-1}$, followed by the Lüleburgaz location with 74.73 $\mathrm{kg} \mathrm{hl}^{-1}$. The TW in the landraces and varieties of durum wheat varied between $77.58-71.83 \mathrm{~kg} \mathrm{hl}^{-1}$. The highest TW among the genotypes was determined in the landrace of Dicle-13 with $77.58 \mathrm{~kg} \mathrm{hl}^{-1}$, followed by the landrace of Dicle with $76.83 \mathrm{~kg} \mathrm{hl}^{-1}$ and Berkmen-469 by $75.50 \mathrm{~kg} \mathrm{hl}^{-1}$. The lowest TW was obtained from the landrace of Iskenderun with 71.83 $\mathrm{kg} \mathrm{hl}^{-1}$. The obsolete cultivar of Beyaziye with 72.04 $\mathrm{kg} \mathrm{hl}^{-1}$ and Yozgat landrace with $73.04 \mathrm{~kg} \mathrm{hl}^{-1}$ were followed (Table 2).

As a result of the analysis of variance in the GVR values, years, locations, genotypes and location $\mathrm{x}$ genotype interactions were found to be statistically significant (Table 2). In the first year of the study, the GVR, which was $88.25 \%$, was determined as $89.7 \%$ in the second year. The highest GVR was found in Tekirdağ with $92.74 \%$, followed by Lüleburgaz with 91.44\%. The lowest GVR was determined in Edirne with $85.20 \%$, followed by Kurklareli with $86.62 \%$. The GVR in the landraces and varieties of durum wheat ranged from 78.42 to $95.08 \%$. The highest GVR among genotypes was obtained in the Akbuğday landrace. The landrace of Iskenderun was followed by this genotype with the rate of $94.91 \%$ of the GVR and Çanakkale with a ratio of 93.33\%. The lowest GVR was obtained in Mardin landrace with $78.42 \%$. Manisa and Denizli landraces were ranked later with $78.58 \%$ and $80.83 \%$ GVR (Table 2).

In the study, as a result of the analysis of variance for the PC values, years, locations, genotypes and location $\mathrm{x}$ genotype interaction were found statistically significant (Table 2). Additive main effect and multiplication interaction (AMMI) analysis: Genotype, location and genotype by location interactions were estimated by the additive main effect and multiplicative interaction (AMMI) model. Variance analysis of AMMI model for examined characters detected significant effects for genotype, location and genotype by location interaction. The location effect was responsible for the greatest part of the variation, followed by genotype and genotype by location interaction effects. Similar findings were also obtained by Ref. [17] on the additive main effect and multiplicative interaction analysis studies of wheat varieties. When the experimental years were examined, the PC obtained in the first year (15.17\%) was higher than in the second year (15.00\%) (Table 2). The highest PC was found in Edirne location with 15.60\%, followed by Kurklareli location with $15.38 \%$. The lowest PC was determined in Tekirdağ location with $14.22 \%$. The PC among durum wheat genotypes ranged from 15.67 to $14.42 \%$. The highest PC was obtained from the Iskenderun landrace with $15.67 \%$, followed by Akbuğday with $15.66 \%$ and Erzincan landraces with $15.65 \%$. The lowest PC was obtained from Kahramanmaraş with $14.41 \%$, Dicle-13 with 14.59\%, Manisa and Adiyaman with 14.56\%.

\subsection{Biplot Analysis and Graphical Evaluation}

As a result of the biplot analysis of the experiment data conducted in two years and 4 locations, the total variation was $80.47 \%$. In the variation, $58.53 \%$ was by the first major component (PC1) and $21.94 \%$ by the second main component (PC2) (Fig. 1). Ref. [18] stated that in the graphic analysis the first principal component (PCA1) represents cultivar productivity, and the second principal component (PCA2) cultivar stability. According to the biplot chart results (Fig. 1), 2 mega environments were obtained. L1, L4 and L3 constitute the first mega-environment, L2 constitutes the second mega environment. According to these results, it will be sufficient to carry out the improvement works in any environment in the first mega environment and in the L2 locations located in the second mega-environment. According to these results, it will be sufficient to carry out the improvement works in any location in the first mega environment and in the L2 location in the second mega-environment. In the 

Landraces Populations

Table 2 Significance groups and mean values for the examined characters.

\begin{tabular}{|c|c|c|c|c|c|}
\hline Genotypes & $\begin{array}{l}\text { TGW } \\
\text { (g) }\end{array}$ & $\begin{array}{l}\text { TW } \\
\left(\mathrm{kg} \mathrm{hl}^{-1}\right)\end{array}$ & $\begin{array}{l}\text { GVR } \\
(\%)\end{array}$ & $\begin{array}{l}\text { PC } \\
(\%)\end{array}$ & $\begin{array}{l}\text { GY } \\
\left(\mathrm{kg} \mathrm{da}^{-1}\right)\end{array}$ \\
\hline 1. Manisa & 38.541 & $74.83 \mathrm{gh}$ & $78.58 \mathrm{k}$ & $14.59 \mathrm{k}$ & $331.33 \mathrm{~d}-\mathrm{g}$ \\
\hline 2. İzmir & $38.88 \mathrm{~h} 1$ & $75.20 \mathrm{~d}-\mathrm{g}$ & $87.88 \mathrm{~g}$ & $15.49 \mathrm{~b}$ & $310.50 \mathrm{~h} 1$ \\
\hline 3. Bursa & $40.92 \mathrm{~cd}$ & $73.63 \mathrm{k}$ & $85.63 \mathrm{~h}$ & 15.24 de & $315.50 \mathrm{f}-1$ \\
\hline 4. Çanakkale & $42.67 \mathrm{ab}$ & $75.37 \mathrm{c}-\mathrm{f}$ & $94.91 \mathrm{a}$ & 15.18 ef & 302.791 \\
\hline 5. Denizli & 38.711 & $73.63 \mathrm{k}$ & $80.83 \mathrm{j}$ & $14.94 \mathrm{~h}$ & 317.33 e-1 \\
\hline 6. Tokat & 39.21 gh1 & $74.21 \mathrm{ij}$ & 84.96 h1 & $14.62 \mathrm{k}$ & 322.25 e-h \\
\hline 7. Erzincan & 40.42 c-g & $74.63 \mathrm{~h} 1$ & 92.33 bcd & $15.65 \mathrm{a}$ & 309.54 h1 \\
\hline 8. Akbuğday & $42.50 \mathrm{ab}$ & 74.91 e-h & $95.08 \mathrm{a}$ & $15.66 \mathrm{a}$ & 336.00 cde \\
\hline 9. Amasya & 39.08 gh1 & $74.83 \mathrm{gh}$ & 83.171 & $14.95 \mathrm{~h}$ & $311.63 \mathrm{~h} 1$ \\
\hline 10. Yozgat & $40.58 \mathrm{c}-\mathrm{f}$ & 73.041 & $87.88 \mathrm{~g}$ & $15.35 \mathrm{c}$ & $310.63 \mathrm{~h} 1$ \\
\hline 11. İskenderun & 38.461 & $71.83 \mathrm{~m}$ & $93.33 \mathrm{ab}$ & $15.67 \mathrm{a}$ & 303.58 h1 \\
\hline 12. Kahramanmaraş & $42.33 \mathrm{ab}$ & 75.41 cde & $87.75 \mathrm{~g}$ & $14.41 \mathrm{l}$ & $384.83 \mathrm{~b}$ \\
\hline 13. Mardin & $36.58 \mathrm{j}$ & $73.92 \mathrm{jk}$ & $78.42 \mathrm{k}$ & 15.39 bc & 314.08 gh1 \\
\hline 14. Adiyaman & $43.54 \mathrm{a}$ & $74.87 \mathrm{fgh}$ & 92.25 bcd & $14.59 \mathrm{k}$ & 318.17 e-1 \\
\hline 15. Gaziantep & $42.54 \mathrm{ab}$ & $75.75 \mathrm{c}$ & $88.83 \mathrm{fg}$ & $15.10 \mathrm{fg}$ & $347.54 \mathrm{~cd}$ \\
\hline 16. Siverek & 41.58 bc & $74.63 \mathrm{~h} 1$ & 90.08 ef & $14.85 \mathrm{~h} 1$ & $376.42 \mathrm{~b}$ \\
\hline 17. Dicle & $40.13 \mathrm{~d}-\mathrm{h}$ & $76.83 \mathrm{~b}$ & 92.33 bcd & $14.73 \mathrm{j}$ & 419.42 a \\
\hline 18. Dicle-13 & 40.63 cde & $77.58 \mathrm{a}$ & 92.13 bcd & $14.56 \mathrm{k}$ & $405.42 \mathrm{a}$ \\
\hline 19. Bağacak & $39.33 \mathrm{e}-1$ & $74.08 \mathrm{jk}$ & 91.96 bcd & $15.30 \mathrm{~cd}$ & 335.25 cde \\
\hline 20. Kayadere & $39.33 \mathrm{e}-1$ & $73.92 \mathrm{jk}$ & 89.33 efg & $15.46 \mathrm{~b}$ & 303.96 h1 \\
\hline 21. Mersiniye & 41.58 bc & 75.08 d-h & 90.63 def & $15.07 \mathrm{~g}$ & $312.75 \mathrm{gh} 1$ \\
\hline 22. Gökgöl-79 & $41.58 \mathrm{bc}$ & $74.00 \mathrm{jk}$ & $89.88 \mathrm{ef}$ & $15.34 \mathrm{c}$ & 336.13 cde \\
\hline 23. Beyaziye & $39.25 \mathrm{f}-1$ & $72.04 \mathrm{~m}$ & 92.79 bc & $14.88 \mathrm{~h}$ & $334.08 \mathrm{c}-\mathrm{f}$ \\
\hline 24. Berkmen-469 & $39.46 \mathrm{e}-1$ & $75.50 \mathrm{~cd}$ & $93.04 \mathrm{~b}$ & $15.29 \mathrm{~cd}$ & 351.85 c \\
\hline 25. Bintepe & 40.67 cde & $74.131 \mathrm{jk}$ & 91.04 cde & $14.75 \mathrm{ij}$ & 336.13 cde \\
\hline Years 2008 & \multicolumn{2}{|c|}{39.91 b $74.73 \mathrm{a}$} & \multicolumn{2}{|c|}{88.25 b 15.17 a } & 353.27 a \\
\hline 2009 & \multicolumn{2}{|c|}{40.77 a 74.38 b } & \multicolumn{2}{|c|}{89.75 a 15.00 b } & $314.50 \mathrm{~b}$ \\
\hline
\end{tabular}

Means with the same letter are not significantly different from each other $(p \geqslant 0.05)$.

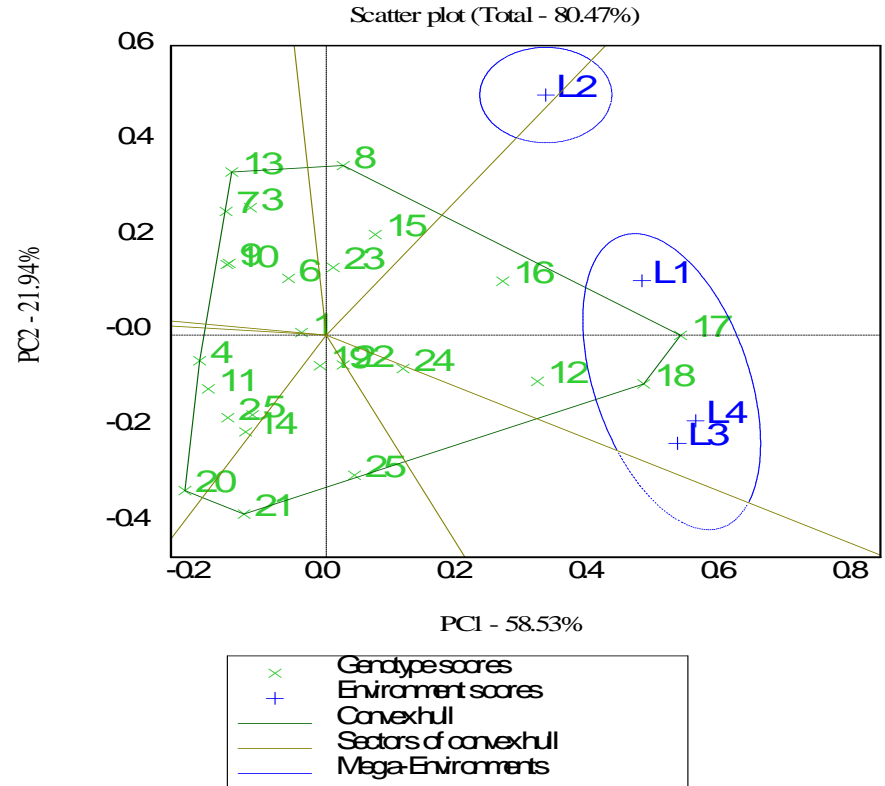

Fig. 1 Biplot graphic showing the relationship between location and variety for $G Y$. 
identification of genotypes and to reveal their existing potentials, only one of the L1, L3, L4 in the first mega environment and L2 in the second mega environment will lead to saving time in terms of time and labor. The GGE biplot showed that the ideal genotype must have a high PCA1 value (high productivity) and a PCA2 value next to zero (more stable). Thus based on the graphic interpretation, the present study showed that, G17 and G18 are determined as the highest GYs in L1, L4 and L3 locations, followed by G12 and G16 in terms of GY. The highest GY was determined in G8 genotype at L2 location. These results were also confirmed to the observations made by Refs. [19-21] on their studies of wheat and barley.

According to the results obtained, the angle between L2 and L1 locations is less than 90 degrees, the angle between L3 and L4 is very low, they are localized close to each other (Fig. 2). These locations can be defined as environments with similar conditions. In addition, it is understood that the L2 location, which is located at the most distant location of the origin, is the most appropriate to discriminate the existing genotypes with the same genetic structure. If the vector length is too large, in other words, it is interpreted as such in the GGE biplot methodology.

Biplot analysis results on genotype showed that it is closest to the line that cuts the graph horizontally and the line that cuts the graph vertically is considered to be efficient and stable (Fig. 3). According to these results, while G17 was determined as the most stable and efficient variety, it was followed by G16, G12 and G18 genotypes. On the other hand, genotypes 20, 21 and 13, which are the farthest to the line that cuts the graph horizontally, are the lowest genotype of yield and stability.

The total variation was $73.78 \%$, and $47.27 \%$ of this variation was made by PC1 and $26.51 \%$ by PC2 (Fig. 4). According to the obtained biplot graph, the varieties were divided into 3 different groups in terms of examined characters. G4, G8 and G14 genotypes had the highest values for grain vitreous and TGW. This result shows that the genotypes have superior

Scatter plot (Total - 80.47\%)
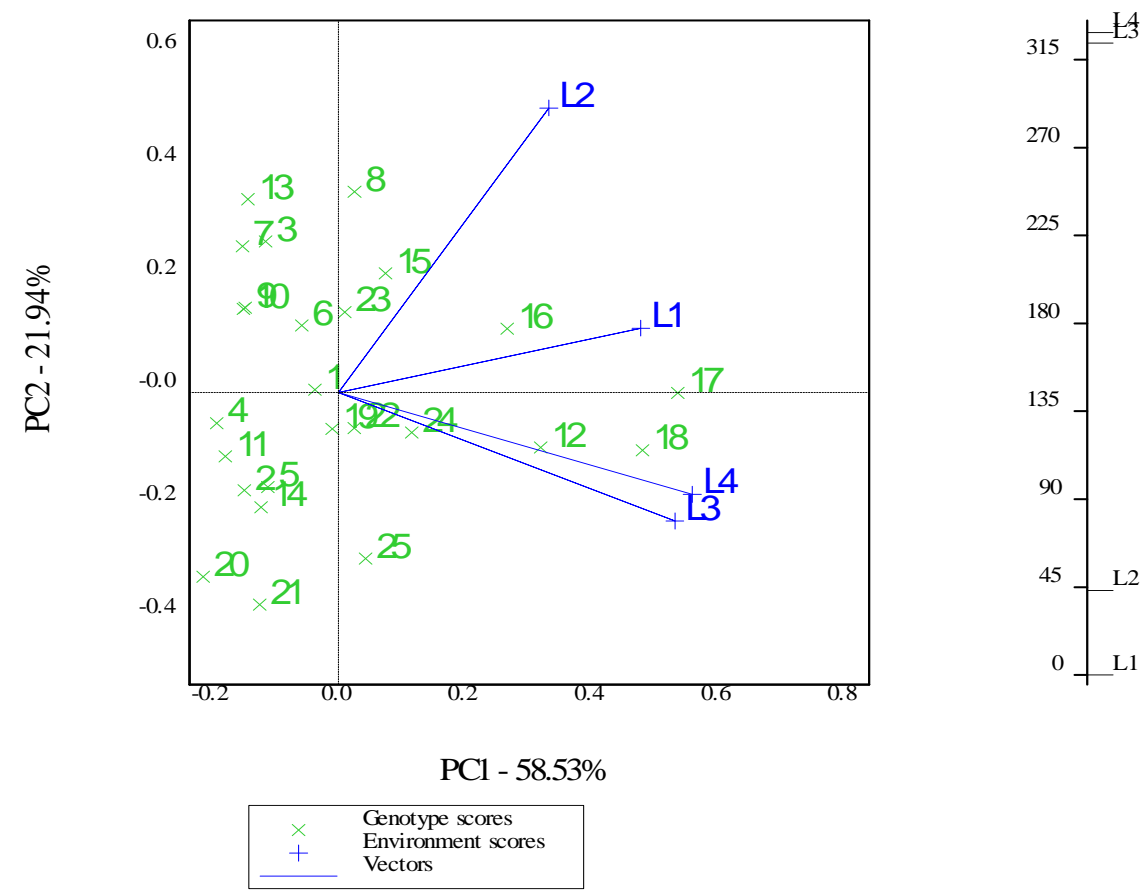

Fig. 2 Biplot graph showing the similarity between locations for GY. 

Landraces Populations

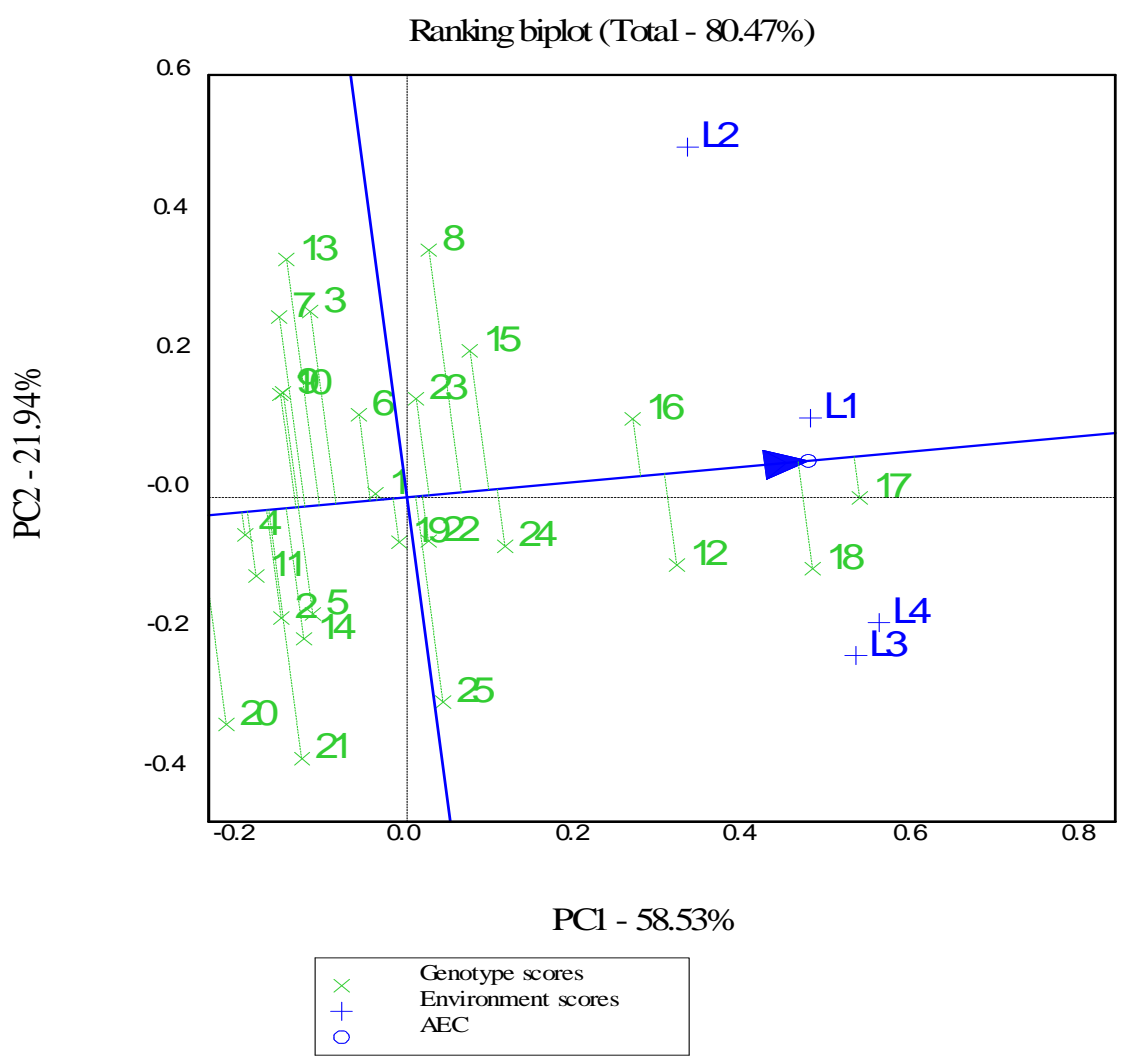

Fig. 3 Biplot graph showing the stability of varieties based on GY.

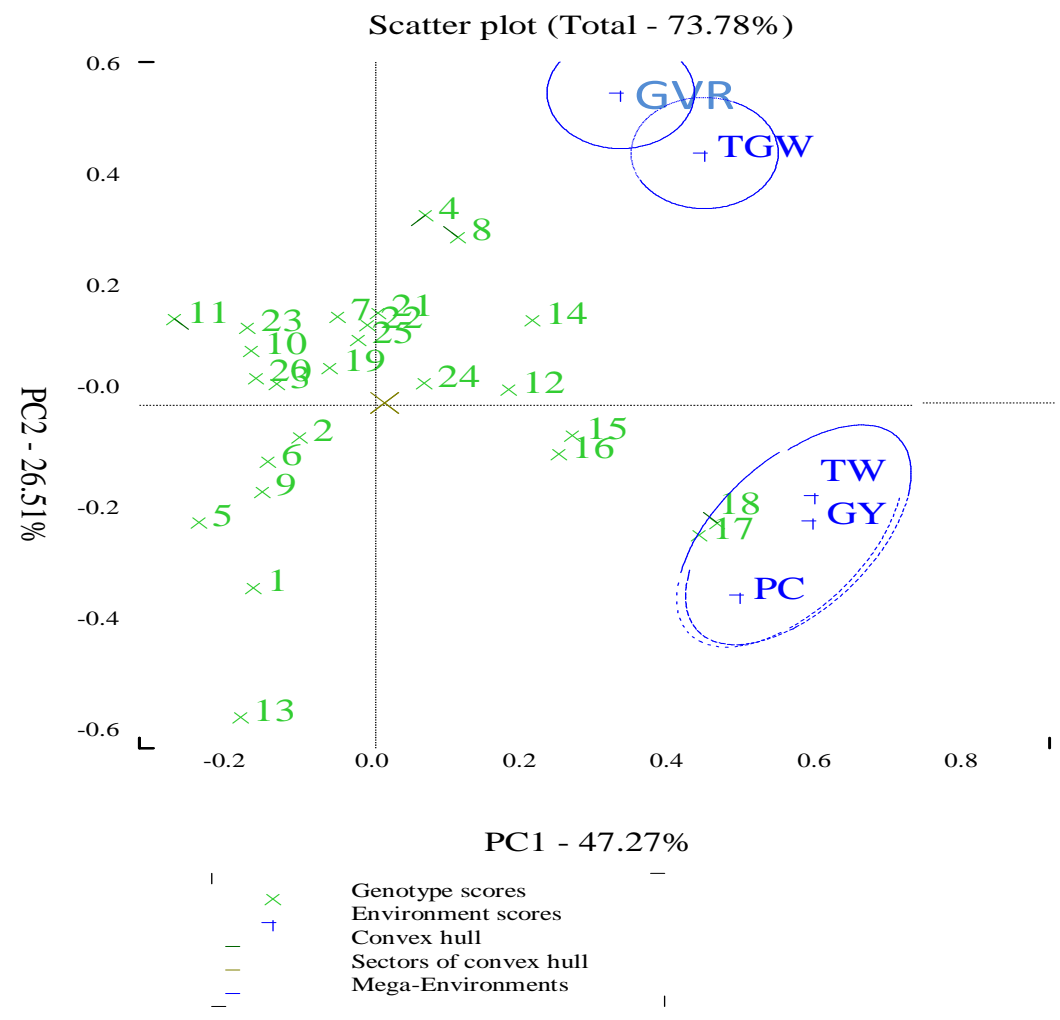

Fig. 4 The biplot graph showing the relationship between varieties and the characters over the two-year averages of locations. 


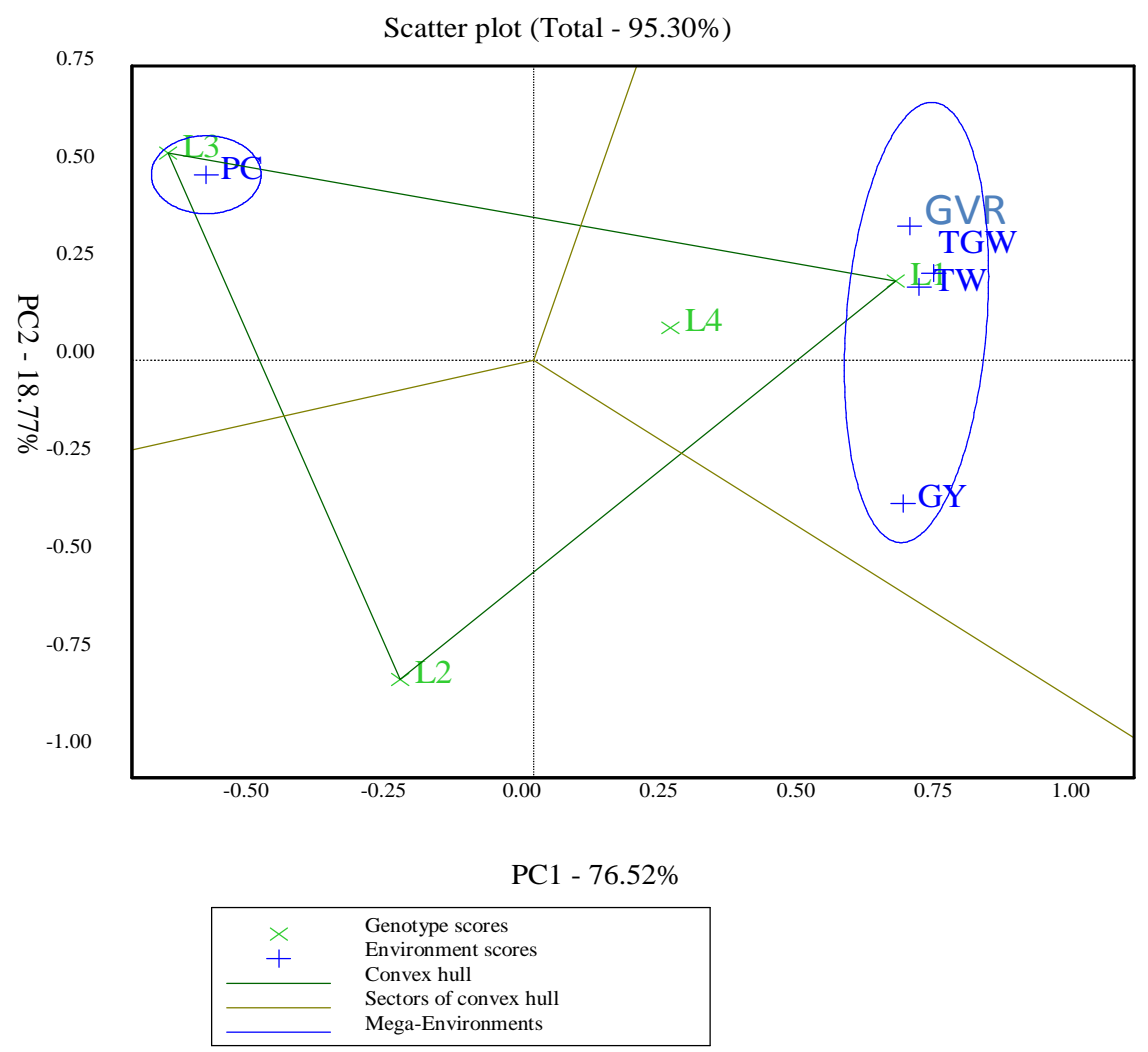

Fig. 5 Biplot graph showing the relationship between $\mathrm{c}$ and varieties with two-year averages of locations.

properties in breeding or production studies in terms of these quality parameters. G17 and G18 varieties were found to have superior properties for GY, TW and protein values.

The genotypes in the diagonal of the polygon obtained in the biplot methodology are considered to be the highest or lowest genotypes for the characters studied. G11 and G13 varieties have no desired or the lowest values for any character. In general, analysis using this AMMI model had been exploited in the variety evaluation of barley [21], wheat [22-26].

Total variation was $95.30 \%$, PC1 was $76.52 \%$ and PC2 was $18.77 \%$ (Fig. 5). The locations located in the diagonal of the polygon obtained in the Biplot methodology are defined as locations with the highest or lowest values for the characters studied (Fig. 5).

Accordingly, the L1 location had the highest values for vitreous, TGW, TW and GY, while the L3 location was the highest or ideal location for the protein ratio. L2 location has the lowest values in terms of examined characteristics. According to the results obtained, L3 location for production with high protein, grain vitreous rate, thousand kernel weight and TW L1 location for GY should be preferred.

\section{Conclusion}

The GY and some quality characters of 20 durum wheat landraces and 5 durum wheat obsolete cultivars provided from different regions of Turkey were examined in 4 different locations during two years in this study. It was determined that the performance of genotypes was different according to locations.

According to the biplot graph results, 2 mega-environments have been formed as L1, L4 and L3 as the first mega-environment and L2 as the second mega environment. G17 and G18 were found in L1, L4 and L3 locations, and G8 was found as the highest GY in L2 location.

The L2 location, which is located at the farthest from the biplot origin, is best defined as the most 
suitable environment to identify the genotypes with similar genetic structure, or to reveal their existing potential.

In biplot analysis, the most distant genotypes to the line closest to the line that cuts the graph horizontally from the center to the vertical line are considered to be efficient and stable. The results showed that G17 was the most stable and the highest yield ability genotype, followed by G16, G12 and G18 genotypes.

G4, G8 and G14 genotypes were found to be the best for GVR and thousand kernel weight characteristics, while G17 and G18 genotypes were found to have superior properties for GY, TW and protein values.

According to the locations in the diagonal of the polygon obtained in the biplot methodology, the L1 location had the highest values for the vitreous, one TGW, TW and GY, while the L3 location was the highest or ideal location for the protein ratio. The L2 location had the lowest values in terms of characteristics.

\section{References}

[1] FAO. 2016. FAO Statistical Databases. (http://www.fao.org/faostat/en/\#data/QC).

[2] Feldman, M., and Millet, E. 2001. "The Contribution of the Discovery of Wild Emmer to an Understanding of Wheat Evolution and Domestication and to Wheat Improvement.” Isr. J. Plant Sci. 49: 25-35.

[3] Ranieri, R. 2015. Geography of the Durum Wheat Crop.” Pastaria Int. 6: 24-36.

[4] Taylor, R. D., and Koo, W. W. 2015. "Outlook of the U.S. and World Wheat Industries, 2015-2024.” Agribus. Appl. Econ. 738: 1-23.

[5] Cantrell, R. G. 1987. "Breeding and Genetics of Durum Wheat.” Plant Breed. Rev. 5: 11-40.

[6] Karagöz, A., and Zencirci, N. 2005. "Variation in Wheat (Triticum spp.) Landraces from Different Altitudes of Three Regions of Turkey.” Genet. Resour. Crop Ev. 52: 775-85.

[7] Agorastos, A. G., and Goulas C. K. 2005. "Line Selection for Exploiting Durum Wheat (T. turgidum L. var. Durum) Local Landraces in Modern Variety Development Program.” Euphytica 146: 117-24.

[8] Kan, M., Küçükçongar, M., Keser, M., Morgunov, A., Muminjanov, H., Özdemir, F., and Qualset, C. 2015.
“Wheat Landraces in Farmers' Fields in Turkey: National Survey, Collection, and Conservation, 2009-2015.” FAO, Turkey.

[9] Ellis, R. P., Foster, B. P., Robinson, D., Handley, L. L., Gordon, D. C., Russell, J. R., and Powell, W. 2000. "Wild Barley: A Source of Genes for Crop Improvement in the 21st Century.” J. Exp. Bot. 51: 9-17.

[10] Jaradat, A. A. 2012. Wheat Landraces: Genetic Resources for Susten. and Sustainability. USDA-ARS, Morris, USA.

[11] Moghaddam, M., Ehdaine, B., and Waines, J. G. 1998. "Genetic Variation for and Interrelationships among Agronomic Traits in Landraces of Bread Wheat from South- Western Iran.” J. Genet. Breed. 52: 73-81.

[12] Keller, L., Schmid, J. E., and Keller, E. R. 1991. “Are Cereal Land Races a Source for Breeding?” Landwirtsch. Schweiz 4: 197-202.

[13] Dotlacil, L. J, Hermuth, Z., and Stehno, Z. 2003. "Earliness, Spike Productivity and Protein Content in European Winter Wheat Landraces and Obsolete Cultivars.” Plant Soil Environ. 49: 67-74.

[14] Abecassis, J. 1991. "Nouvelles possibilities d'apprecier la valeur meuniere et la valeur semouliere des bles.” Ind. Cereals 81: 25-37.

[15] Novaro, P., Colucci, F., Venora, G., and D’Egidio, M. G. 2001. "Image Analysis of Whole Grains: A Non-invasive Method to Predict Semolina Yield in Durum Wheat." Cereal Chem. 89: 217-21.

[16] Dexter, J. E., and Edwards, N. M. 1998. "The Implications of Frequently Encountered Grading Factors on the Processing Quality of Common Wheat." Association of Operative Millers Bulletin 7: 7115-22.

[17] Tarakanovas, P., and Ruzgas, V. 2006. "Additive Main Effect and Multiplicative İnteraction Analysis of Grain Yield of Wheat Varieties in Lithuania.” Agronomy Research 4 (1): 91.

[18] Yan, W., Hunt, L. A., Sheng, Q., and Szlavnics, Z. 2000. "Cultivar Evaluation and Mega-Environment İnvestigation Based on the GGE Biplot.” Crop Science 40: 597-605.

[19] Dehghani H., Ebadi, A., and Yousefi, A. 2006. "Biplot Analysis of Genotype by Environment Interaction for Barley Yield in Iran.” Agron. J. 98: 388-93.

[20] Tesfaye, L., Egidio, M. G. D., and Abinasa, M. 2008. "Analysis of Multi-environment Yield Trials in Durum Wheat Based on GGE-Biplot.” Journal of Food, Agriculture \& Environment 6 (2): 217-21.

[21] Abay, F., and Bjornstad, A. 2009. "Specific Adaptation of Barley Varieties in Differentlocations in Ethiopia." Euphytica 167 (2): 181-95.

[22] Gebru, H., Mariam, A. H., and Belay, T. 2011. "Genotype by Environment İnteraction and Grain Yield: Stability of 


\section{Landraces Populations}

Early Maturing Bread Wheat (Triticum aestivum L.) Genotypes in the Drought Prone Areas of Tigray Region, Northern Ethiopia.” EJAST 1 (2): 3.

[23] Mohammed Maarouf, I. 2009. “Genotype x Environment Interaction in Bread Wheat in Northern Sudan Using AMMI Analysis." American-Eurasian J. Agric. \& Environ. Sci. 6 (4): 427-33.

[24] Korkut, K. Z., Bilgin, O., Baser, I., and Saglam, N. 2007. "Stability of Grain Vitreousness in Durum Wheat (Triticum durum L. Desf.) Genotypes in the
North-Western Region of Turkey.” Turk J Agric. 31: 313-8.

[25] Farshadfar, E. 2008. "Incorporation of AMMI Stability Valueand Grain Yield in a Single Non-parametric İndex (GSI) in Bread Wheat.” Pakistan Journal of Biological Sciences 11 (14): 1791-6.

[26] Bilgin, O., Balkan, A., Korkut, K. Z., and Başer, İ. 2017. "Multi-environmental Evaluation of Triticale, Wheat and Barley Genotypes by GGE Biplot Analysis.” Journal of Life Sciences 12: 13-23. 